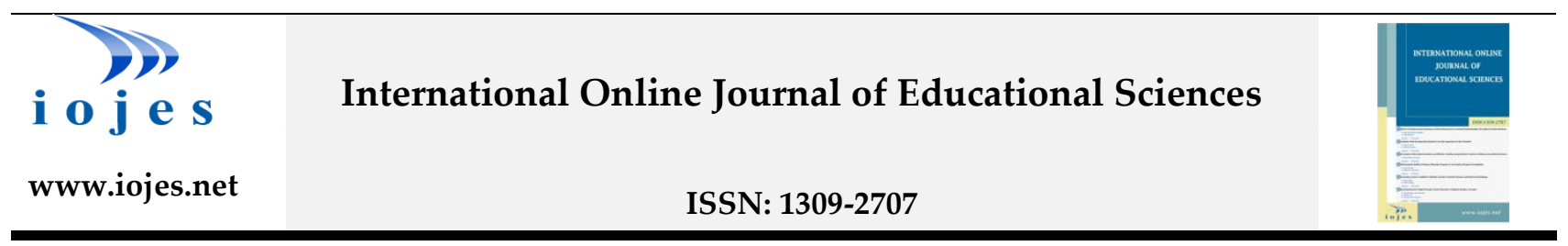

\title{
Determination of Democracy Awareness Levels of Teacher Candidates
}

\author{
Research Article
}

\section{Alpaslan GOZLER ${ }^{1}$}

${ }^{1}$ Erciyes University, Faculty of Education, Department of Basic Education, Kayseri, Turkey, ORCID: 0000-0002-0543-4524

To cite this article: Gozler, A. (2021). Determination of democracy awareness levels of teacher candidates, International Online Journal of Educational Sciences, 13(2), 592-603.

\begin{tabular}{ll} 
ARTICLE INFO & ABSTRACT \\
\hline Article History: & $\begin{array}{l}\text { This research aims to determine teacher candidates democracy awareness levels according to various } \\
\text { variables. Within the framework of this general purpose, the dependence of the democracy } \\
\text { awareness levels of teacher candidates on different variables including gender, department, grade } \\
\text { Received: 01.01.2020 }\end{array}$ \\
level, place of residence and grade point average were also examined. For data collection, the \\
Democratic Awareness Scale was administered to 248 teacher candidates enrolled at a university in \\
th.05.2021 \\
the district of Kayseri. The data were analyzed by carrying out the t-test, one-way variance analysis, \\
and Tukey test. Results of the analysis revealed that democratic awareness levels of the teacher \\
candidates were at the "I agree" level. While gender and class level of teacher candidates had no \\
significant influence on democratic awareness, department and place of residence significantly \\
influenced democratic awareness of the teacher candidates. There was higher participation from the \\
students in the Elementary Education and Turkish Language departments compared to the students \\
in Social Studies Education department, and that there was higher participation from the students \\
living with their families compared to the students living alone or in dormitories. The results of the \\
study were discussed with the previous studies. Suggestions were provided according to the results..
\end{tabular}

Keywords:

(C) 2021 IOJES. All rights reserved

Teacher candidate, democracy, democratic awareness, democratic education

\section{Introduction}

Social life is arranged with the rules around specific values that are required to be internalized by individuals as a network of relationships. The existence of such rules presents suitable conditions to eliminate the obscurity in social life, to be the one learning in relationships among individuals, and to identify the liberty, responsibility, rights, and limitations of individuals (Altinkurt \& Karakose, 2009; Demirkasımoğlu, 2015). In terms of establishing and maintaining an order in social life, awareness of an individual about his rights and liberties, realizing his responsibilities, and the prevalence of equality and justice are essential (Demirbolat,

${ }^{1}$ Corresponding author's address: Erciyes University

Telephone: +905395782323

e-mail: agozler@erciyes.edu.tr

DOI: https://doi.org/10.15345/iojes.2021.02.018 
1999; Duman, Yavuz, and Karakaya, 2016). On the other side, democracy is an invention having a social context and is a notion following the unity of these values and rules (Okutan, 2010).

Democracy is not a monotype formation. It is challenging to create a concrete definition of democracy because ideal democracy consists of the values, preferences, and expectations of the creators determining its standard and is the re-interpretation of democracy with these elements (Tamer, 2011). Democracy based on the sovereignty of the people gives precedence to the value of individual so that it can make the social order regular and healthy as much as possible. Also, democracy, called 'the regime based on the sovereignty of society' in the dictionary of Turkish Language Institute (TLI), is the opposite of autocracy and is a notion in which the majority has a voice instead of oppression.

In the studies, it is stated that democracy, which means self-governance in the political frame, is regarded as not only a regime but also an applicable lifestyle practiced in every aspect of life (Duman, 2016; Özpolat, 2010). Education has an essential role in providing the social order in which living together is accessible at the highest level via the main elements of democracy (Başaran, 2005; Maboçoğlu, 1999) like selfcontrol, liberty, equality, justice, rights, and participation. The process of the education of democracy ideally started in familiesshould be sustained in schools.

\section{Democracy and Education}

Although the direction, method, and tools of education show some differences from time to time, the true and foremost purpose of democracy is to transform the human. Within this context, countries aim to educate individuals as "a-good citizens" with the education programs. In the frame of this objective, an education atmosphere preparing the individual for real-life conditions is created. Yağcl (1998) put forward that one of the most significant functions of education is to raise the individuals that have faith in democracy and interiorize democratic attitudes and behaviors as their way of life.

Due to its nature, the relationship between education and democracy has bidirectional character (Yeşil, 2002). While democracy needs education in order to improve, education will be able to provide the reliable and desired results only in democratic environments. In one respect, they are both purpose and tool for each other.

When it is presumed that the essential characteristic of learning emerges with "repetition and experience", it is possible to claim that the only way for individuals to comprehend and adopt democracy and to perpetuate it in their daily life is through education. In other words, students, who experience and internalize the learning environments where democratic understanding prevails, can raise as an applicator of democracy in real life.

It can be stated that democracy, which is frequently pronounced in theory, is not fully integrated into our educational system in the context of practice. Özpolat (2010) states that it is not given efficient place for education in the content and practices of philosophy because the pre-conditions of democracy such as questioning and transparency are regarded as the factors that make social control difficult, education is not efficiently put forward in philosophical context and practices.

The education of democracy is the realization of the principles and values, linked with democracy, by creating a connection with real-life conditions and current problems in the dimensions of school culture, curriculum and educational practices within the scope of educational policies (Emir and Kaya, 2004; Karakose, 2015; Okutan, 2010; Özpolat, 2010; Tamer, 2011; Yağcl, 1998).

The education of democracy seems to be essential and necessary in today's conditions. According to Özpolat (2010), when the diversities in our country's socio-cultural structure against new threatens, as well as the opportunities created by globalization and information technologies, are taken into account, it is possible 
to pursue the culture of social integration and peaceful coexistence only by developing an understanding relied on democratic values. On this point, it can be said that the continuity of democratic societies will be provided by the presence of democratic education and teaching and with the teachers trained in such environments.

According to Başaran (2005), the entitling of the freedoms of thought, conscience, will and action to the students make the democratic understanding possible in the learning environments. He also emphasizes that the objectives of democracy education will be realized to a great extent when the student has the right to know and practice his rights and to take part in decisions and matters that affect himself, and when he acquires the skill of controlling his behaviors.

Teachers can gain knowledge, attitudes, and skills, shaping the elements of democracy in the democratic classroom order where students are educated (Kayabaş1, 2011). Besides the pressure felt by students caused due to the absolute authority, the uncontrolled situation stemming from excessive liberty are also considered as the most significant obstacles to the democratization of the classroom environment. That the teacher takes on the tasks of guiding, directing, and facilitating the teaching processes is the ideal within the context (Özpolat, 2010; Yirci, Karakose, Uygun \& Ozdemir, 2016). In addition to these roles, accepted by the teacher, enabling the self-discipline / self-control mechanisms of the student, the discussion of the negativities or mistakes and of development of their solutions that will emerge in the classroom environment figured by the cooperation of teachers and students is precious in terms of enabling democratic perception to spring in the mind of the student (Taşdan and Kantos, 2007). Yağc1 (1998) also marks that it is crucial to assure that the dynamics of being scientific, participation, and respect are stable in providing a democratic environment within the classroom on the condition that external barriers are achieved.

While preparing a democratic environment, a teacher should gain the confidence and respect of the students first, and then present favorable conditions for commitment and sense of belonging of the students. The student receiving the awareness of democracy by feeling and witnessing gain democratic perception gradually. In other words, the teacher becomes a role model for his students (Bandura and Walters, 1977). What the teacher is expected to do for the sake of democratic understanding directs to the source of the solution to higher education institutions training teachers. As in the other education levels, it will be appropriate to confront the teacher candidates, who are required to be trained as democratic teachers, with the correct examples and practices raising awareness of teacher candidates in terms of the fundamental values of democracy (Tuncel and Balc1, 2015; Yağc1, 1998).

In Turkey, various studies related to democratic perception of teachers, teacher candidates, and students were conducted. The studies can be counted as the impact of teacher qualifications on student's democratic behavior development (Tuncel and Balc1, 2015), determining the perception of democracy developed by teachers (Sarı and Sadık, 2011; Kartal, 2018), democratic attitude (Bulut, 2006; Erbay and Ömeroğlu, 2012; Genç and Kalafat, 2007; Koçoğlu, 2013), the democratic behavior of instructors (Samancı and Yıldırım, 2015) and instructors' perception of learning and teaching of democratic values (Oğuz, 2011), democratic values (Çermik, 2013), and the perception of democracy in art education (Konak and Bulut, 2018). On the other hand, this study aims to determine teacher candidates' perception of democracy according to some variables. For this purpose, the following research questions were answered:

1) What is the mean score of democracy awareness scores of teacher candidates?

2) Does teacher candidates' awareness of democracy differ significantly by gender?

3) Does teacher candidates' awareness of democracy differ significantly according to the classes?

4) Does teacher candidates' awareness of democracy differ significantly according to the department they study? 
5) Does teacher candidates' awareness of democracy differ significantly according to the Grade Point Average (GPA)?

6) Does teacher candidates' awareness of democracy differ significantly according to the place of residence?

\section{Method}

The research is conducted with a survey model. Survey models are based on the objective of observing any occasion, individual, or object, which is the subject of the research within the context of their conditions. For this research, cross-sectional method among survey methods were used (Fraenkel, Wallen, and Hyun, 2011; Karasar, 2015).

\section{Sample}

The participants of the research consisted of teacher candidates in the faculty of education of a university located in the Kayseri district. The sample of the study consisted of the four-year students of the elementary school, Turkish language, social sciences, sciences and mathematics departments. Purposive sampling, a sampling method with which the researcher determines a subgroup that represents the study universe as the sample. The teacher candidates in the departments of Elementary Education, Turkish Language, Social Sciences, and Mathematics were introduced with the study. Although there were a total of 400 students, 266 agreed to participate. Among them, 18 responses were dropped out due to missing data. Therefore, responses from 248 students were included in the data analysis process.

Table 1. The Demographics of Teacher Candidates

\begin{tabular}{|c|c|c|c|}
\hline & & $\mathbf{n}$ & Percentage $(\%)$ \\
\hline \multirow{2}{*}{ Gender } & Female & 199 & 80.2 \\
\hline & Male & 49 & 19.8 \\
\hline \multirow{5}{*}{ Department } & Language & 61 & 24.5 \\
\hline & Education & & \\
\hline & Social Studies Education & 59 & 23.7 \\
\hline & Elemantary Education & 62 & 25 \\
\hline & Mathematics Education & 64 & 25.8 \\
\hline \multirow[t]{5}{*}{ Class Level } & 1 & 58 & 23.4 \\
\hline & 2 & 62 & 25 \\
\hline & 3 & 64 & 25.8 \\
\hline & 4 & 64 & 25.8 \\
\hline & $2.00-2.60$ & 84 & 33.8 \\
\hline \multirow[t]{2}{*}{ GPA } & $2.61-3.40$ & 78 & 31.6 \\
\hline & $3.41-4.00$ & 86 & 34.6 \\
\hline \multirow[t]{3}{*}{ Residence } & With family & 92 & 37 \\
\hline & Own place & 76 & 30.8 \\
\hline & Dormitory & 80 & 32.2 \\
\hline Total & & 248 & 100.0 \\
\hline
\end{tabular}

Table 1 shows that 80.2 percent of students were female students and 19.2 percent were male students. When examined according to the department and class level differences, the distributions were close to each other. Besides, while 37 percent of the students live with their family, others live in their own place or in dormitory. 


\section{Data collection tool}

In the study, the Democracy Awareness Scale (DAS), developed by Akan (2011) was used. Although the scale was administered to the high school students, Akan (2011) stated that it may be used for other education levels. The scale consists of 24 items with one dimension. As a result of the validity and reliability analysis of the scale, it was observed that corrected item-total correlations were between .46 and .75 , and internal consistency coefficient was .91. Explanatory factor analysis (EFA) was run by the researcher to confirm the factor structure of the DAS. Results of the EFA showed that the KMO Measure of Sampling Adequacy coefficient was .890, and the value of Barlett's sphericity was 2230,426 ( $<<.001)$. As a result of EFA, one dimensional structure was obtained and the structure explained 33,83 of the total variance. Tavşancl (2005) emphasizes that $30 \%$ or more of explained total variance is enough for one dimensional structure; therefore, this value was considered as acceptable as. The factor structure of the researcher was similar with the Akan (2011)'s factor structure. For the rest of the analysis, the total score of the DAS was used for analysis. As the scale was designed as 5 point Likert type, the scores can be obtained from the scale are between 24 and 120. Therefore, 60 point is considered as average level while evaluating the scores. Besides, higher scores means higher levels of democratic awareness of the participants.

\section{Data Analysis}

Before the analysis process, normality of the data was checked. Normality assumption was satisfied for parametric analyses as the skewness and kurtosis values of the data were between -2 and +2 . In the analyses of the data, a t-test was used to determine the differences between the groups according to the gender variable, while one-way variation analysis was used to determine the differences between the groups in terms of the place of residence, department, and point averages of the students when two variables were involved. For the items pointing to the significant differences among groups, the analysis was made by using the Tukey test as the Tukey test uses the Honest Significant Difference to represent the distance between groups and to compare each mean score with the other mean scores

\section{Findings}

The results regarding participants' DAS scores are given in Table 2.

Table 2. Results of DAS

\begin{tabular}{cccc}
\hline DAS & $\mathbf{n}$ & $\boldsymbol{X}$ & SD \\
\cline { 2 - 4 } & 248 & 79.72 & 16.96 \\
\hline
\end{tabular}

Total 248 cases were analyzed. The mean score of the DAS was 79.72 with standard deviation 16.96. As the mean score was above 60 , teacher candidates' democratic awareness level was above the average. Their awareness level was good.

In Table 3, the results regarding gender difference were provided.

Table 3. Results of $\mathrm{t}$ test variable by gender

\begin{tabular}{|c|c|c|c|c|c|c|}
\hline \multicolumn{7}{|c|}{ Awareness Scale) } \\
\hline & Male & 199 & 84.14 & 17.09 & & \\
\hline & Female & 49 & 80.77 & 16.38 & 1.246 & .214 \\
\hline
\end{tabular}


According to the results, no statistical significant difference was observed ( $\mathrm{p}>.05)$. When Table 3 is examined it can be seen that in terms of the gender variable the male participants had higher democracy awareness $(X=84.14)$ than the female participants $(X=80.77)$.

The results regarding class level differences were provided in Table 4.

Table 4. Results of one-way ANOVA variance analysis variable by class level

\begin{tabular}{|c|c|c|c|c|c|c|}
\hline DAS & & Sum of Squares & df & Mean Square & $\mathbf{F}$ & $\mathbf{P}$ \\
\hline & Intergroup & 635.492 & 3 & 211.831 & .734 & .533 \\
\hline & Intragroup & 70700.532 & 245 & 288.574 & & \\
\hline & Total & 71336.024 & 248 & & & \\
\hline
\end{tabular}

As seen in Table 4, it was observed that there was no statistical significant difference according to their class level ( $p>.05)$. The results showed that class levels of the students did not influence their democratic awareness levels.

Responses of teacher candidates were examined based on their department. The results are provided in Table 5.

Table 5. Results of one-way variance analysis in terms of department The Tukey test results according to the department variable

\begin{tabular}{|c|c|c|c|c|c|}
\hline & Sum of Squares & df & Mean Square & $\mathbf{F}$ & p \\
\hline Intergroup & 5157.939 & 3 & 1719.313 & $6.365^{*}$ & .000 \\
\hline Intragroup & 66178.085 & 245 & 270.115 & & \\
\hline Total & 71336.024 & 248 & & & \\
\hline \multicolumn{2}{|c|}{ (I) Department - (J) Department } & \multicolumn{3}{|c|}{ Difference between averages (I-J) } & $\mathrm{p}$ \\
\hline \multirow[t]{3}{*}{ Turkish E. } & Social Studies E. & & $11.34535^{*}$ & & .001 \\
\hline & Elemantary E. & & -1.64693 & & .939 \\
\hline & Mathematics E. & & 4.62157 & & .318 \\
\hline \multirow[t]{3}{*}{ Social Studies E. } & Turkish E. & & $-11.34535^{*}$ & & .001 \\
\hline & Elemantary E. & & $-12.99228^{*}$ & & .001 \\
\hline & Mathematics E. & & -6.72378 & & .157 \\
\hline \multirow[t]{3}{*}{ Elemantary E. } & Turkish E. & & 1.64693 & & .939 \\
\hline & Social Studies E. & & $12.99228^{*}$ & & .001 \\
\hline & Mathematics E. & & 6.26851 & & .169 \\
\hline \multirow[t]{3}{*}{ Mathematics E. } & Turkish E. & & -4.62157 & & .318 \\
\hline & Social Studies E. & & 6.72378 & & .157 \\
\hline & Elemantary E. & & -6.26851 & & .169 \\
\hline
\end{tabular}

According to the results, a significant difference was observed according to their departments $\left(\mathrm{F}_{(3,24)}=\right.$ 6.36, $\mathrm{p}<.05)$. Due to the significant result, Tukey test was performed to determine the source of difference. The results of Tukey test are presented in Table 5.

When point averages of the participants are analyzed according to their departments, the significant difference between elementary school teacher candidates and social studies teacher candidates, and between Turkish Language teacher candidates and social studies teacher candidates were observed $(p<.05)$. it can be said that elementary school teacher candidates and Turkish language teacher candidates had higher democratic awareness than that of social studies teacher candidates.

The participants' DAS scores were examined based on their GPA. The results are provided in Table 6. 
Table 6. Results of one-way variance analysis variable by GPA of the participants

\begin{tabular}{lccccc}
\hline & Sum of Squares & df & KO & F & P \\
\hline Intragroup & 942.538 & 3 & 314.179 & 1.093 & .353 \\
Intergroup & 70393.486 & 245 & 287.320 & & \\
Total & 71336.024 & 248 & & & \\
\hline
\end{tabular}

No significant difference was observed among the teacher candidates in terms of their GPA ( $p>05)$. This result indicated that GPA of the students did not influence their democratic awareness levels.

The participants' DAS scores were examined based on their place of residence. The results are provided in Table 7.

Table 7. Results of one-way variance analysis variable by place The Tukey test results according to the place variable

\begin{tabular}{rrrrrc}
\hline & Sum of Squares & df & Mean Square & F & p \\
\hline Intergroup & 1701.323 & 2 & 850.661 & $3.052^{*}$ & .049 \\
Intragroup & 68294.871 & 245 & 278.755 & \\
Total & 69996.194 & 247 & & $\mathrm{p}$ \\
\hline (I) Residence $-(\mathrm{J})$ Residence & \multicolumn{2}{c}{ Difference between averages (I-J) } & .114 \\
\hline Dormitory & With family & & 8.47124 & .769 \\
& Own place & -1.57440 & .114 \\
Own place & Dormitory & -8.47124 & .038 \\
& With family & & $-10.04564^{*}$ & .769 \\
With family & Dormitory & & 1.57440 & .038
\end{tabular}

${ }^{*} \mathrm{p}<.05$.

According to the results, a statistical significant was observed based on participants' place of residence $\left(\mathrm{F}_{(2,245)}=3,052, \mathrm{p}<.05\right)$. Due to the significant result, Tukey test was performed to determine the source of difference. It was observed that the students living with their families had higher democratic awareness than that of the students living in their own place. No other significant differences were determined between other comparisons.

\section{Discussion and Conclusion}

When it is assessed in terms of its components, democracy is quite profound. It is required to acquire liberty, tolerance, and the awareness of right and responsibility for polyphony and democracy. The presence of these concepts in all units of any society lays the way open for democratization. In the contrary case, this expression will not go further than discourse.

The quality of democracy perception and awareness is essential for the individuals who are expected to be grown up as good citizens and for the teacher candidates who will undertake this duty. The results of this study revealed that the teacher candidates' democratic awareness level was "I agree" to a large extent. It may be predicted that teacher candidates growing up with a high level of democratic awareness will arrange and maintain a democratic classroom environment for their students in the future (Biçer, 2007; Güven, 2007).

According to the results of the study, there were no significant mean differences in DAS scores of the teacher candidates in terms of their gender, class level and GPA. However, it was noted that there was significant mean differences among the teacher candidates regarding their department and residence. Furthermore, there were significant differences between Turkish Language teacher candidates and social studies teacher candidates, and elementary school teacher candidates and social studies teacher candidates. 
Moreover, it was observed that significant mean difference was occurred with the teacher candidates' residence variable between the students living with their parents, and students renting their own places.

The findings obtained from the study showed that democratic awareness did not change according to gender. Even though there was no significant difference among genders, it can be marked that female students had higher democratic consciousness compared to male students. In other studies, it was determined that there was no significant difference between the students' democracy awareness levels of according to gender variable (Biçer 2007; Büyükkaragöz 1990; Saracaloğlu, Uça, and Başara, 2013). On the other hand, in their studies, Yanardag (2000) and Simsek (2011) determined that female students had higher democratic attitude compared to the male students. In the literature, when compared with earlier studies focusing on democratic attitude, perception, and behavior, this finding corresponds to some studies but conflicts with the others. For instance, it is parallel with the finding reached by Kayabaşı (2011), concluding that there was no difference in the level of teacher candidates' use of democratic principles according to gender. Güven, Kaya and Aslan (2014) also put forward that gender did not create a decisive difference. Similar results were obtained for social studies teachers (Tuncel and Balci, 2015). In their study Baltaci and Aydin (2019) determined gender differences. The results of the studies analyzing democratic behaviors (Kesici, Pesen and Oral, 2017) and democratic attitudes (Bulut, 2006; Elkatmış and Toptaş, 2015; Ömerustaoğlu, 2004) support the findings of the current study. Contrary to the studies mentioned above, Saracaloğlu, Evin, and Varol (2004) found that there was no difference in teachers' democratic attitudes according to gender, and that, among teacher candidates, female candidates had more democratic attitudes compared to male candidates as in Genç and Kalafat (2007) and Ekici (2014).

Another finding of the study is that democratic awareness did not differ according to class level. Some research results support this finding (Ekici, 2014; Genç and Kalafat, 2007). On the other hand, Güven, Kaya, and Aslan (2014) stated that there was a difference in democratic attitudes according to class level.

A difference in the context of democratic awareness according to the department of teacher candidates was observed. This finding shows that the average levels of democratic awareness of Turkish Language and Elementary School teacher candidates were significantly higher than that of the Social Studies teacher candidates. Therefore, it was found that Turkish Language teacher candidates and elementary school teacher candidates had higher democratic awareness than Social Studies teacher candidates. In the literature, there exist different results about whether democratic consciousness, attitude, or behavior differs according to departments. Bulut (2006) put forth that science teachers' democratic attitudes levels were higher than those of Psychological Counseling and Guidance (PCG) teacher candidates. Ömerustaoğlu (2004) stated that the Mathematics teacher candidates and Philosophy teacher candidates had higher democratic attitudes than the students in the other departments (Ömerustaoğlu, 2004) and Aydemir and Aksoy (2010) found that social sciences teacher candidates had higher democratic attitudes than that of the students in the other teacher education programs. Çermik (2013) stated that PCG teacher candidates had lower democratic values than teacher candidates in the Music Education, Turkish Language Education, Elementary Education, Social Studies Education departments. Moreover, Kayabaşı (2014) shared the finding that there was no difference among the maojors in terms of acceptance of the principles of democracy by teacher candidates categorized as numerical and verbal fields. Ocak, Karakuş, and Ocak (2018) reported that differences in department did not affect communication skills. On the other hand, Saracaloğlu at al. (2013) determined that the democratic attitude of students studying in the early childhood education department was higher than those studying in the other departments. While the different sample groups and measurement tools may be the reason for the difference in the findings obtained from the studies, this situation can also be explained by the variation in the values and/or perception of democracy. 
Another finding of the study is related to whether the students' democratic awareness levels differ according to the participants' GPA. Some studies focused on secondary school students, it was revealed that perceptions of democracy increase as academic success increases (Akan, 2011; Ersöz and Duruhan, 2015; Sarıçam and Özbey, 2018). In this study, the reason that students' democratic awareness levels did not differ according to their GPA can be associated with the moral development of the participants. Kohlberg's moral development levels are generally divided into three periods, including pre-traditional, traditional, and posttraditional periods. While in the pre-traditional period, one's moral development is quite primitive; there is a high level of moral development in the post-traditional period (Kohlberg and Hersh, 1977). Within this context, the level of moral development of the participants with a high level of democratic awareness can coincide with the post-traditional period, involving concepts such as human rights and freedom, and based on the idea that laws can be changed democratically. This situation may not be linked with academic success. Hence, it may not impact the democratic awareness level of the participants' GPAs.

A significant difference was observed in participants' democratic awareness levels according to their places of residence. In other words, the average level of democratic awareness of the students living with their families was higher than the students living in the student apartments and dormitories. Bingol (2000) also reported that the students' place of residence had an effect on the democratic structure.

\section{Suggestions}

This study is limited to describing the democratic awareness levels of teacher candidates. Longitudinal studies on democratic awareness or democratic attitude will contribute to the literature.

In the study, it was identified that there was no significant difference between male and female students. However, both groups had democratic awareness at the average level. Studies should be carried out to increase the democratic awareness levels of teacher candidates. Student club activities, projects and other events that increase the democratic attitudes of the students should be particularly carried out during undergraduate education. Similarly, activities including professional development programs, courses, and seminars should be arranged to develop the democratic attitudes of the students. 


\section{REFERENCES}

Akan, Y. (2011). Orta öğretimde okuyan öğrencilerin demokrasi bilinci (Sakarya örneği). Unpublished Master's Thesis. Sakarya University Graduate School of Educational Sciences. Sakarya.

Altinkurt, Y., \& Karakose, T. (2009). İlköğretim okulu müdürlerinin etik liderlik davranışlarına ilişkin öğretmen görüşleri. Dumlupınar Üniversitesi Sosyal Bilimler Dergisi, 24, 269-280.

Ataç, L. O. \& Köse, S. (2017). Örgütsel demokrasi ve örgütsel muhalefet ilişkisi: Beyaz yakalılar üzerine bir araştırma. İstanbul Üniversitesi İşletme Fakültesi Dergisi, 46(1), 117-132.

Aydemir, H., \& Aksoy, N. D. (2010). Eğitim fakültesi öğrencilerinin demokratik tutumlarının bazı değişkenlerle ilişkisi: Malatya örneği. Erzincan Üniversitesi Ĕ̆itim Fakültesi Dergisi, 12(1), 265-280.

Baltacı A. ve Aydın, Y. (2019) Din kültürü ve ahlak bilgisi öğretmenlerinin demokratik tutumları. Şırnak Üniversitesi İlahiyat Fakültesi Dergisi. 10(22), 58-78

Bandura, A., \& Walters, R. H. (1977). Social learning theory (Vol. 1). Englewood Cliffs, NJ: Prentice-hall.

Başaran, İ. E. (2005). Ĕ̆itim psikolojisi: Gelişim, öğrenme ve ortam. Nobel.

Biçer, B. (2007), Demokrasi eğitimi ve okul meclisleri projesi ile öğrencilerde demokratik kültür kazanımlarının ortaöğretim öğretmenlerince değerlendirilmesine yönelik bir analiz, Unpublished Master's Thesis, Dumlupınar University Graduate School of Social Sciences, Kütahya.

Bïngöl, D. (2010). Demokratik tutum ve değerler açısından üniversite gençliği. Atatürk Üniversitesi İktisadi ve İdari Bilimler Dergisi, 14(1), 129-157.

Bulut, N. (2006). Bir grup üniversite öğrencisinin demokratik tutumları ile çeşitli değişkenler arasındaki ilişkiler. Kuram ve Uygulamada Eğitim Yönetimi Dergisi, 12(1), 37-59.

Büyükkaragöz, S. (1990), Demokrasi eğitimi ve okul, Demokrasi Dergisi, 19, Ankara.

Çermik, H. (2013). Öğretmen adaylarının demokratik değerleri ve bu değerlerin bazı değişkenler açısından incelenmesi. Education Sciences, 8(2), 261-274.

Demirkasımoğlu, N. (2015). Toplum yaşamında kurallar: Birey-kural ilişkisi. Manisa Celal Bayar Üniversitesi Sosyal Bilimler Dergisi, 13(1), 138-156.

Duman, T., Yavuz, N. \& Karakaya, N. (2016). İnsan hakları ve demokrasi vatandaşlık bilgisi. Pegem Atıf İndeksi, 2016(3), 1-184.

Ekici, F. Y. (2014). Öğretmen adaylarının demokratik tutumları ve demografik özellikleri arasındaki ilişkinin incelenmesi. Turkish Studies, 9(11), 593-602.

Elkatmış, M., \& Toptaş, V. (2015). Sınıf öğretmeni adaylarının demokratik tutumlarının incelenmesi. Yüzüncü Yll Üniversitesi Ĕ̆itim Fakültesi Dergisi, 12(1), 128-144.

Emir, S., \& Kaya, Z. (2004). Demokrasi eğitimi ve okul meclislerine yönelik öğretmen görüşleri. Abant İzzet Baysal Üniversitesi Ĕ̆itim Fakültesi Dergisi, 4(8), 69-89.

Erbay, F. \& Ömeroğlu, E. (2012). Okul öncesi öğretmenlerin demokratik tutumlarının drama uygulama yeterlilikleri açısından incelenmesi. Türkiye Sosyal Araştırmalar Dergisi, 171(171), 171-188.

Ersöz, Y., \& Duruhan, K. (2015). Okul ortamında demokrasi yaşantıları. İnönü Üniversitesi Eğitim Bilimleri Enstitüsü Dergisi, 2(3), 13-26.

Fraenkel, J. R., Wallen, N. E., \& Hyun, H. H. (2011). How to design and evaluate research in education. New York: McGraw-Hill Humanities/Social Sciences/Languages.

Genç, S. Z., \& Kalafat, T. (2007). Öğretmen adaylarının demokratik tutumları ile problem çözme becerilerinin çeşitli değişkenler açısından incelenmesi. Pamukkale Üniversitesi Ĕ̆itim Fakültesi Dergisi, 22(22), 10-22.

Güven, A. (2010). Tarih öğretiminde öğrencilerin demokratik tutumlarinin bireysel değişkenler açisindan incelenmesi. Atatürk Üniversitesi Kazım Karabekir Ë̆itim Fakültesi Dergisi, 15, 36-61 
Güven, A., Kaya, R., \& Aslan, H. (2014). Tarih öğretmen adaylarının demokratik tutumlarının çeşitli değişkenler açısından incelenmesi. Middle Eastern \& African Journal of Educational Research 12 17-31.

Karaçalı Taze, H., Aktın, K . (2019). Ortaokul öğretmenlerinin demokratik davranış eğilimleri. Abant İzzet Baysal Üniversitesi Ĕ̆itim Fakültesi Dergisi, 19 (1) , 270-281

Karakose, T. (2015). The Relationship between medical students' time management skills and academic achievement. Studies on Ethno-Medicine, 9(1), 19-24.

Karasar, N. (2015). Bilimsel araştırma yöntemi. Nobel Akademik Yayıncılık. Ankara

Kartal, A., Öksüz,Y., Öztürk, B. M.\& Demir, G.E. (2018). Sınıf öğretmeni adaylarının demokrasi algısı: Polonya-Türkiye karşılaştırması. İlköğretim Online, 17(2), 562-579.

Kayabaşı, Y. (2011). Öğretmen adaylarının davranışlarının demokratik sınıf ortamı açısından değerlendirilmesi. Gazi Üniversitesi Gazi Ĕ̆itim Fakültesi Dergisi, 31(2), 525-549.

Kesici, A., Pesen, A., \& Oral, B. (2017). Öğretmenlerin sınıf içi demokratik davranışlarının çeşitli değişkenlere göre incelenmesi. Elektronik Sosyal Bilimler Dergisi, 16(60), 34-45.

Koçoğlu, E. (2013). Sosyal bilgiler öğretmen adaylarının, okul yöneticilerinde olması gereken demokratik tutum ve davranışlara ilişkin görüşleri. Electronic Turkish Studies, 8(6), 413-430.

Kohlberg, L., \& Hersh, R. H. (1977). Moral development: A review of the theory. Theory into Practice, 16(2), 5359.

Konak, A., \& Bulut, Ü. (2018). Türkiye'de sanat eğitimcisi ve sanat eğitimi bağlamında demokrasi bilinci. Illköğretim Online, 17(2), 1002-1013.

Ocak, G., Karakuş, G. \& Ocak, İ. (2018). Öğretmen adaylarının tartışma becerileri ile iletişim becerileri arasındaki ilişkinin incelenmesi. Trakya Üniversitesi Sosyal Bilimler Dergisi, 20 (1), 299-317

Oğuz, A. (2011). Öğretmen adaylarının demokratik değerleri ile öğretme ve öğrenme anlayışları. Değerler Ĕ̆itimi Dergisi, 9(22), 139-160.

Okutan, M. (2010). Türk Eğitim Sistemi'nde demokrasi eğitimi. Uluslararası İnsan Bilimleri Dergisi, 7:1. Erişim: http://www.insanbilimleri.com

Ömerustaoğlu, A. (2004). Felsefe grubu öğretmenliği ve diğer anabilim dallarında öğrenim gören öğrencilerin demokratik tutumlarının çeşitli değişkenler açısından incelenmesi. Sakarya Üniversitesi Eğitim Fakültesi Dergisi, 7, 216-226.

Özpolat, A. (2010). Bir toplumsal değişme paradigması olarak demokrasinin eğitime yansımaları: Demokratik eğitim. Milli Ĕ̆itim Dergisi, 40(185), 365-381.

Rainer, J. ve Guyton, E. (1999). "Democratic practices in teacher education and the elementary classroom" [ilköğretim sınıflarında ve öğretmen eğitiminde demokrasi uygulamaları]. Teaching and Teacher Education, 15, 121-132.

Samancı, O., \& Yıldırım, G. (2015). Sınıf öğretmeni adaylarına göre öğretim elemanlarının demokratik ve demokratik olmayan tutum ve davranışları. Atatürk Üniversitesi Sosyal Bilimler Enstitüsü Dergisi, 19(1), 115-128.

Saracaloğlu, A. S., Evin, İ., \& Varol, S. R. (2004). İzmir ilinde çeşitli kurumlarda görev yapan öğretmenler ile öğretmen adaylarının demokratik tutumları üzerine karşılaştırmalı bir araştırma. Kuram ve Uygulamada Eğitim Bilimleri Dergisi, 4(2), 335-363.

Saracaloğlu, A, Uça, S, Başara Baydilek, N, Coşkun, N. (2013). Öğretmen adaylarının demokratik tutumları ile değer algılarının incelenmesi. Adnan Menderes Üniversitesi Ĕ̆itim Fakültesi Ĕ̆itim Bilimleri Dergisi, 4 (1), 45-59.

Sarı, M. \& Sadık, F. (2011). Öğretmen Adaylarının Demokrasi Algıları (Çukurova Üniversitesi Örneği). International Journal of Curriculum and Instructional Studies, 1(2), 67-82. 
Sarıçam, H., \& Özbey, A. (2018). Ortaokul öğrencilerinde demokrasi algısı, deontik adalet, toplumsal değerler algısı arasındaki ilişki. Ege Eğitim Dergisi, 19(1), 161-181.

Selvi, K. (2006). Developing a teacher trainees' democratic values scale: validity and reliability analyses. Social Behavior and Personality: An International Journal, 34(9), 1171-1178.

Sencer M. (1989) Sencer, M. (1989). Toplumbilimlerinde yöntem. Beta Basım. İstanbul

Tamer, M. G. (2011). Okulların demokratik ve katılımcı öğrenim ortamlarına dönüştürülmesi (Demokratik okul yönetimi). Milli Ĕ̆itim Dergisi, 41(192), 7-25.

Tavşancıl, E. (2005). Tutumların Ölçülmesi ve SPSS ile Veri Analizi. Ankara: Nobel Yayınevi

Taşdan, M. \& Kantos, Z. E. (2007). Sınıf yönetimi ve disiplin. (İç. Cafoğlu, Z.). Sinıf yönetimi, 9-42.

Tuncel, G. \& Balcı, A. (2015). Demokratik toplumlarda öğretmen nitelikleri ve öğrencilere yansımaları. Marmara Coğrafya Dergisi, (31), 82-97.

Yağcl, E. (1998). Demokrasi ve eğitim. Eğitim ve Bilim, 22 (107), 15-22.

Yeşil, R. (2002). Okul ve Ailede İnsan Hakları ve Demokrasi Eğitimi, Nobel Yayınevi, Ankara.

Yanardağ, A. (2000), Üniversite gençliğinin demokratik tutum ve davranışları üzerine bir araştırma (Selçuk Üniversitesi örneği), Unpublished Master's Thesis, Selçuk University, Graduate School of Social Sciences, Konya.

Yirci, R., Karakose, T., Uygun, H., \& Ozdemir, T. Y. (2016). turkish adaptation of the mentorship effectiveness scale: A validity and reliability study. Eurasia Journal of Mathematics, Science and Technology Education, $12(4), 821-832$. 